\title{
DESIGN OF ANTIGEN SYNTHESIS AND PREPARATION AND CHARACTERIZATION OF SPECIFIC AND EURYTOPIC ANTIBODIES AGAINST B-GROUP AFLATOXINS
}

\author{
Yanan Wang \\ postgraduate student \\ Sumy National Agrarian University (Sumy, Ukraine) \\ College of Animal Science and Veterinary Medicine, Henan Institute of Science and Technology (Xinxiang, China) \\ ORCID: 0000-0001-9537-2947 \\ wyn564@126.com \\ Hanna Fotina \\ Doctor of Veterinary Sciences, Professor \\ Sumy National Agrarian University (Sumy, Ukraine) \\ ORCID: 0000-0002-0761-3681 \\ hanna.fotina@snau.edu.ua
}

The aim of this study was to prepare B-group aflatoxins(BGAFs) antibody with strong specificity and good eurytopicity. According to the molecular structure and active site of aflatoxin $B 1\left(A F B_{1}\right)$, the BGAFs artificial antigen $A F B_{1}-B S A$ was prepared by 6 methods such as oxime active ester(OAE), methylation of ammonia(MOA),mixed anhydride(MA),semi acetal(SA),epoxide(EP) and enol ether derivative(EED) and identified by UV and SDS-PAGE. Polyclonal antibodies against $A F B_{1}\left(A F B_{1}\right.$ pAb) were prepared by immunizing New Zealand rabbits with $A F B_{1}-B S A$, and the titers of $A F B_{1} p A b$ was detected by indirect ELISA, the sensitivity of $A F B_{1}$ $p A b$ was analyzed by indirect competitive ELISA(icELISA) and the specificity and eurytopicity of AFB 1 pAb was analyzed by crossreactivity $(C R)$ test. The results showed that $A F B_{1}-B S A$ was synthesized successfully and the best one was OAE method among 6 synthesis methods of BGAFs artificial antigen and its conjugation ratio of $A F B_{1}$ to $B S A$ was about $8.46: 1$. The immune efficacy of $O A E$ method was the best, its $A F B_{1} p A b$ had high titers of $1: 1\left(28 \times 10^{4}\right)$ by indirect ELISA, a good sensitivity with the $50 \%$ inhibition concentration $\left(I C_{50}\right)$ of $10.32 \mu \mathrm{g} / \mathrm{L}$ to $A F B_{1}$ by icELISA and a high CR to $A F B_{2}$ of $75.21 \%$, AFG 1 of $44.13 \%, A F G_{2}$ of $14.72 \%, A F M 1$ of $16.36 \%$ and $A F M_{2}$ of $1.44 \%$, respectively. In this study, $A F B_{1}$ pAbs with high titer, sensitivity, specificity and eurytopicity were prepared, which laid a matter and technical foundation for the establishment of BGAFs immunoassay.

Key word B-group aflatoxins, antigen synthesis design, polyclonal antibody, characteristics analysis

DOI: https://doi.org/10.32845/bsnau.vet.2020.4.8

Introduction. Aflatoxins (AFs) are a group of toxic secondary metabolites containing similar molecular structures (difuran ring and oxyheteronaphthalidone). They are produced by Aspergillus flavus and Aspergillus parasiticus through the polyketone pathway. At present, more than 20 members of the aflatoxin (AF) family have been found in food pollution. Among them, $A F$ of group $B$ ( $B$ group aflatoxins, BGAFs) have strong toxicity, wide pollution, and high content. Various toxic effects such as carcinogenicity, teratogenicity and immunosuppressiveness have become the main targets of food AF contamination detection (Sun D.D et.al., 2015). BGAFs include AFB 1 and $A F B_{2}$, both of which are closely related to food pollution, and both exist at the same time, mainly $A F B_{1}, A F B_{2}$ pollution is accompanied by $A F B_{1}$, and has a toxic additive effect (Luo, $X$. et. al., 2018). Therefore, there are two regulations for the maximum residue limits (MRLs) of BGAFs in foods. the current AFB1 MRL standard of foodand agricultural products in China is "GB 2761-2017 limit of fungal toxins in food" which One is that some countries including my country adopt $A F B_{1} M R L s$, such as the current $A F B_{1} M R L$ standard of food and agricultural products in China is "GB 2761-2017 limit of fungal toxins in food" (CHINA. National Food Safety Standard Limit of mycotoxins in food. 2017 ), corn and its products $\leq 20 \mu \mathrm{g} \cdot \mathrm{kg}^{-1}$, rice and its products $\leq 10 \mu \mathrm{g} \cdot \mathrm{kg}-1$, wheat and its products $\leq 5 \mu \mathrm{g} \cdot \mathrm{kg}-1$. Second, some countries use MRLs for the total amount of BGAFs $\left(B_{1}+B_{2}\right)$, such as EU $\leq 4 \mu \mathrm{g} \cdot \mathrm{kg}^{-1}$, Japan $\leq 10 \mu \mathrm{g} \cdot \mathrm{kg}^{-1}$, and US FDA $\leq 15$ $\mu \mathrm{g} \cdot \mathrm{kg}^{-1}$. There are many current analytical methods for food BGAFs contamination, mainly using instrumental analysis and

immunoassay. In particular, immunoassay has become a technology because of its strong specificity, high sensitivity, simple operation, large-scale screening and on-site detection. Indispensable technical means, the key to establishing a BGAFs immunoassay method is to obtain excellent antibodies, and hapten design and antigen synthesis are the prerequisites for preparing excellent antibodies (Gefen T.et. al., 2015). There have been related reports on the research of BGAFs antigen synthesis methods at home and abroad (Mongkon, W. et. al., 2017, Xiao L.W, et. al., 2017), but there are no reports on the design of different hapten molecules, antigen synthesis and comparative analysis of antibody characteristics. In this study, $\mathrm{AFB}_{1}$ was used as the starting material for the reaction. Polyclonal antibodies (pAbs) were prepared through different $A_{F} B_{1}$ hapten molecular design and antigen synthesis methods, and their characteristics were analyzed to screen out the best hapten and antigen synthesis methods. It lays the foundation for the preparation of high-quality monoclonal antibodies of BGAFs with high sensitivity, broad recognition spectrum and strong specificity (Zhou, Y. et. al., 2007).

Aim The aim of this study was to prepare B-group aflatoxins (BGAFs) antibody with strong specificity and good eurytopicity.

\section{Materials and Methods}

Main reagents, solutions and experimental animals $A F B_{1}, A F B_{2}, A F G_{1}, A F G_{2}$ standard products, Singapore Pribolab product; Cationized bovine serum albumin (CBSA), goat anti-rabbit enzyme-labeled secondary antibody (GaRlgG- 
HRP), American Sigma product. The diluent used in the enzyme-linked immunosorbent assay (ELISA) is $0.01 \mathrm{~mol} \cdot \mathrm{L}^{-1}$ $\mathrm{pH7.4}$ phosphate buffer solution (PBS); the washing solution is PBS containing $0.5 \mathrm{~g} \cdot \mathrm{L}^{-1}$ Tween-20 (PBST); the blocking solution is PBST containing $50 \mathrm{~g} \cdot \mathrm{L}^{-1}$ porcine serum; the coating solution is $0.1 \mathrm{~mol} \cdot \mathrm{L}^{-1}$ carbonate buffer solution (CBS) with $\mathrm{pH}$ 9.6. The experimental animals were 18 male New Zealand white rabbits at the age of 2 months and weighing $1 \pm 0.2 \mathrm{~kg}$. They were provided by the Experimental Animal Center of Xinxiang Medical College. They were divided into 6 groups, each with 3 rabbits.

BGAFs artificial antigen synthesis design

According to the active sites on the molecular structure of AFB1 (Figure 1), the following six methods are proposed to prepare artificial antigen AFB1-BSA (Table 1).<smiles>COc1cc2c(c3oc(=O)c4c(c13)CCC4=O)C1C=COC1O2</smiles>

Fig.1 Molecular structure of AFB

Table1

The hapten design and antigens synthesis of AFB1






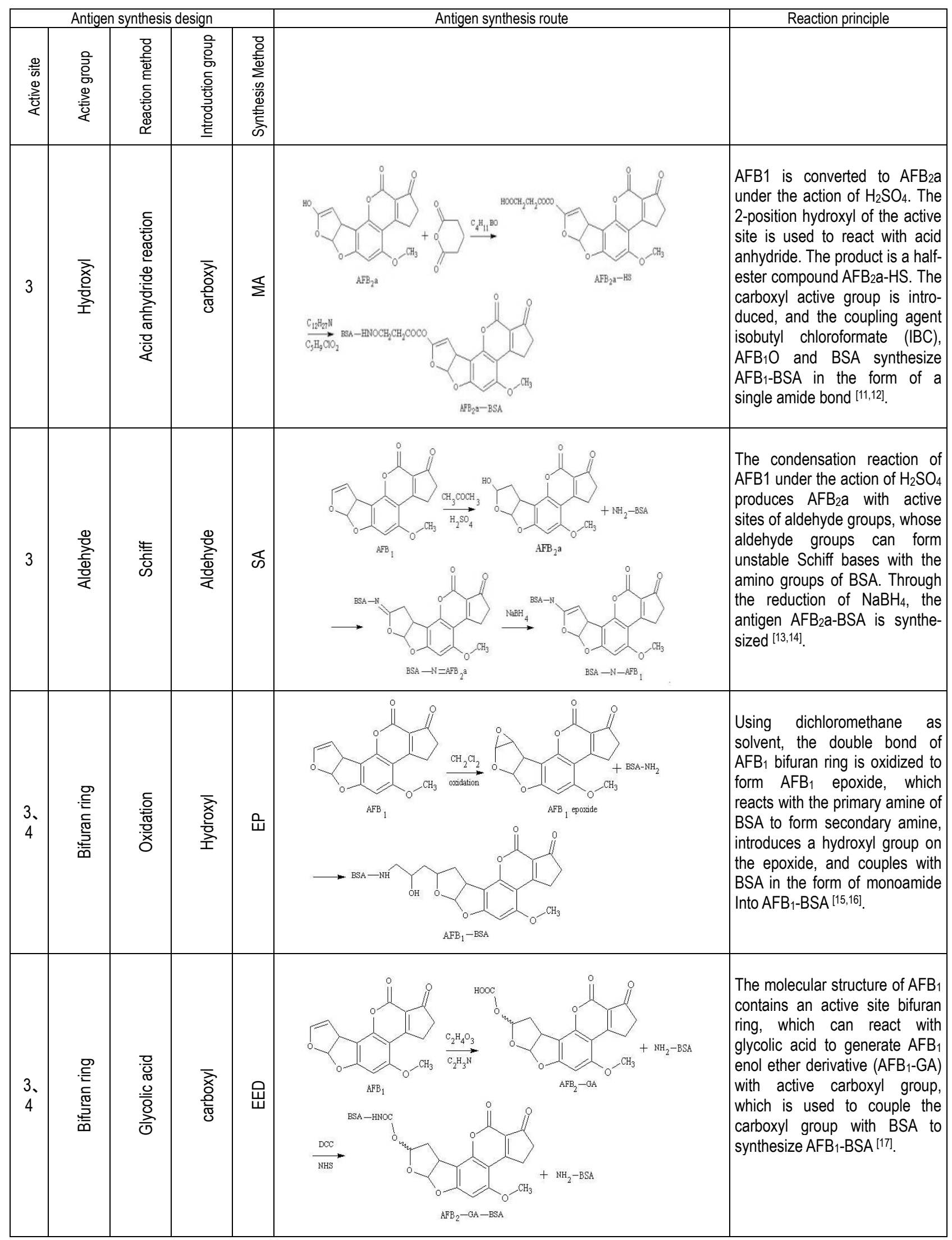

BGAFs artificial antigen identification

UV Scan

Dissolve $A F B_{1}$ with methanol, prepare $1 \mathrm{mg} \cdot \mathrm{mL}^{-1} A F B_{1}$ solution; use volume ratio (v/v) 4:6 methanol PBS solution to dissolve $B S A$ and $A F B_{1}-B S A$, prepare $1 \mathrm{mg} \cdot \mathrm{mL}^{-1} B S A$ and
$\mathrm{AFB}_{1}$ - BSA solution; UV scan at a wavelength of $200 \sim 500 \mathrm{~nm}$, through the calculation formula $A=\varepsilon C L$ (where $A$ is the absorbance value, read by the instrument; $\varepsilon$ is the molar extinction coefficient, which is a constant value; $C$ is the solute concentration in the solution; $L$ is Optical path, determined by the instru- 
ment), calculate the molecular binding ratio of $\mathrm{AFB}_{1}$ and $\mathrm{BSA}$ (Wang Y.N. et. al., 2014).

SDS-PAGE identification

The concentration of the concentrated gel and the separating gel are selected to be $5 \%$ and $12 \%$, the voltage is $90 \mathrm{v}$ and $60 \mathrm{v}$, the sample volume is $10 \mu \mathrm{L}$ per well, and the protein content is $10 \mu \mathrm{g}$ per well. The UV analyzer system software calculates $A F B_{1}$ and $B S A$ the molecular binding ratio.

Preparation of AFB1 pAb

The artificial antigens synthesized by 6 different methods were used to immunize New Zealand white rabbits. Each antigen was used to immunize 1 group, a total of 6 groups, 3 rabbits in each group. The immunization dose is calculated according to the amount of protein BSA in AFB1-BSA, each is $100 \mu \mathrm{g}$, the volume is $1 \mathrm{~mL}$, the back is injected subcutaneously at 4 to 6 points, a total of 5 immunizations, each interval is 3 to 4 weeks, after the fifth immunization for 2 weeks, blood was collected from the ear vein, the polyantiserum was separated by centrifugation, and the polyantiserum was purified by the saturated ammonium sulfate salting-out method to prepare AFB1 pAb (Ju RH et. al., 2015).

Characteristic analysis of AFB1 pAb

Determination of potency Indirect ELISA (Zhao HH et. al., 2015).

\section{Sensitivity identification}

Indirect competitive ELISA (icELISA) measures the half inhibitory concentration (IC50) of AFB1 pAb on AFB1 to determine sensitivity (Chen T et. al., 2014).

Specific identification

With AFB1, AFB2, AFG1, and AFG2 as inhibitors, the IC50 of each inhibitor was determined by icELISA, and the percentage of the IC50 of AFB1 pAb to AFB1 and the IC50 of other inhibitors was used as the cross-reaction rate (CR\%) (Zhang $C$ et. al., 2016), the calculation method is CR\% = IC50 of AFB1 pAb to AFB1/ IC50×100 of AFB1 pAb to other inhibitors.

\section{Results}

GAFs artificial antigen identification results

UV identification

The results are shown in Figure 2. In the range of UV200500 nm, the characteristic peak of BSA is at $278 \mathrm{~nm}$, and the characteristic peak of AFB1 is at $363 \mathrm{~nm}$. The artificial antigen AFB1-BSA is synthesized by 6 methods including OAE, MOA, MA, SA, EP, EED. Both contain the characteristic peaks of BSA and AFB1, indicating that the above 6 methods can synthesize artificial antigen AFB1-BSA. The calculated results of the molecular binding ratio of BSA to AFB1 (Liu, H.X. et. al., 2014) are shown in Table 2.

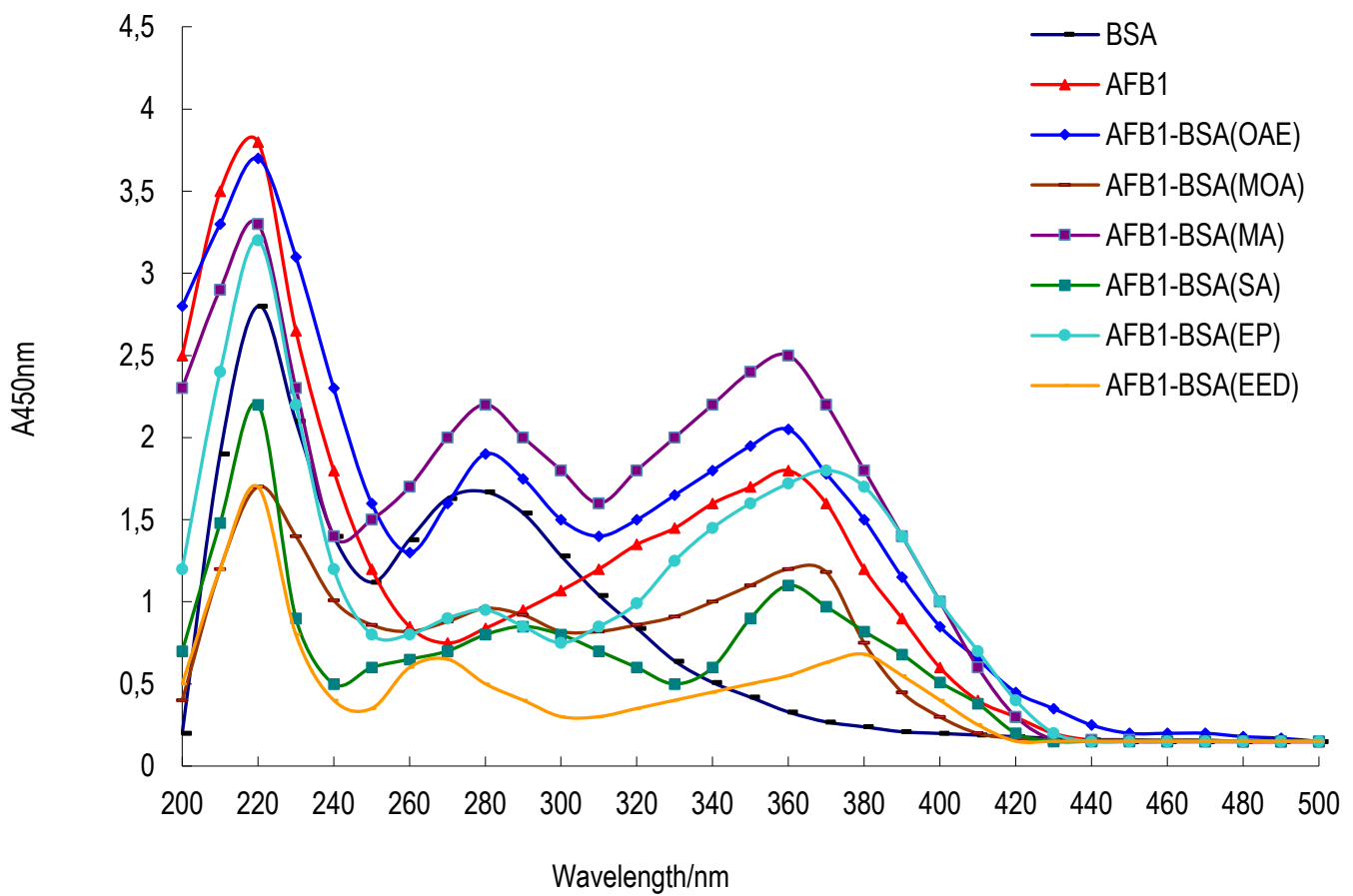

Fig.2 UV spectra of $A F B_{1}-B S A$

Molecular binding ratio of $\mathrm{AFB}_{1}-\mathrm{BSA}$ prepared by six methods

\begin{tabular}{|l|l|l|l|}
\hline \multicolumn{1}{|c|}{ Synthesis methods } & \multicolumn{1}{|c|}{ Initial molar ratio of $\mathrm{AFB}_{1}$ to BSA } & \multicolumn{1}{c|}{ Molecular binding ratio of $\mathrm{AFB}_{1}-\mathrm{BSA}^{-1}$} & \\
\hline OAE & $50: 1$ & $8.64: 1$ & 17.28 \\
\hline MOA & $50: 1$ & $6.88: 1$ & 13.76 \\
\hline MA & $50: 1$ & $10.78: 1$ & 21.56 \\
\hline SA & $50: 1$ & $4.46: 1$ & 8.92 \\
\hline EP & $50: 1$ & $6.38: 1$ & 12.76 \\
\hline EED & $50: 1$ & $2.31: 1$ & 4.62 \\
\hline
\end{tabular}

Note: Compared to the molecular weight of BSA and $A F B_{1}, B S A$ is $66.446, A_{1} B_{1}$ is $312, B S A$ is much larger than $A F B_{1}$, so the utilization rate of $B S A$ is $100 \%$ when the utilization ratio is calculated.

SDS-PAGE identification

The results are shown in Figure 3. It can be seen that 
the bands of the 6 artificial antigens AFB1-BSA lag behind the bands of BSA, indicating that the molecular weight of AFB1-
BSA is greater than that of BSA, and it can be determined that the synthesis of $A F B_{1}-B S A$ is successful.
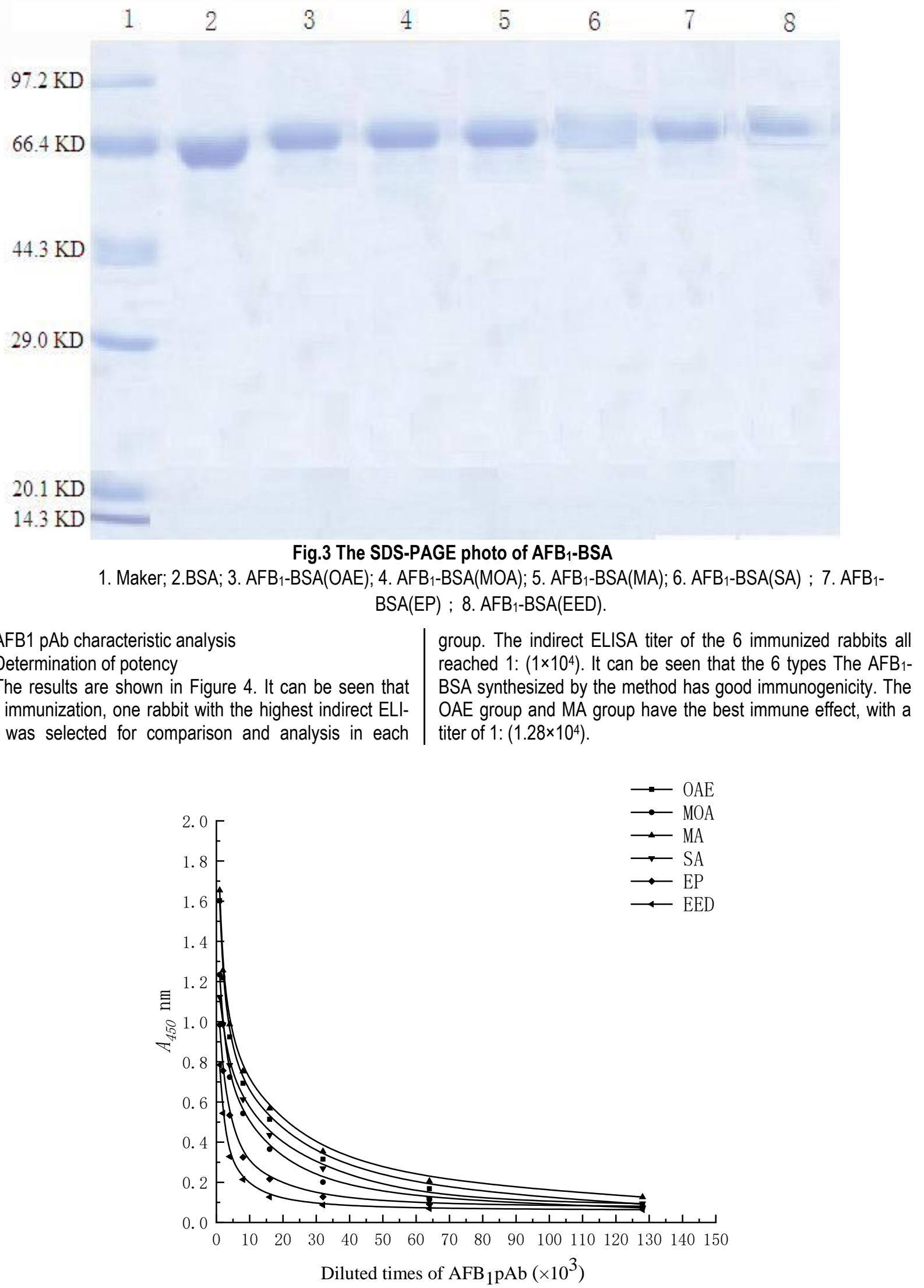

Fig.4 The indirect ELISA titer curves of $\mathrm{AFB}_{1} \mathrm{pAb}$ 
Sensitivity analysis

The results are shown in Figure 5 . It can be seen that the icELISA inhibition curve of 6 immunized rabbits has a good linear relationship. The OAE group has the best sensitivity, with an $\mathrm{IC}_{50}$ of $10.32 \mu \mathrm{g} \cdot \mathrm{kg}^{-1}$. The sensitivity of the other groups is inferior to that of the OAE group.

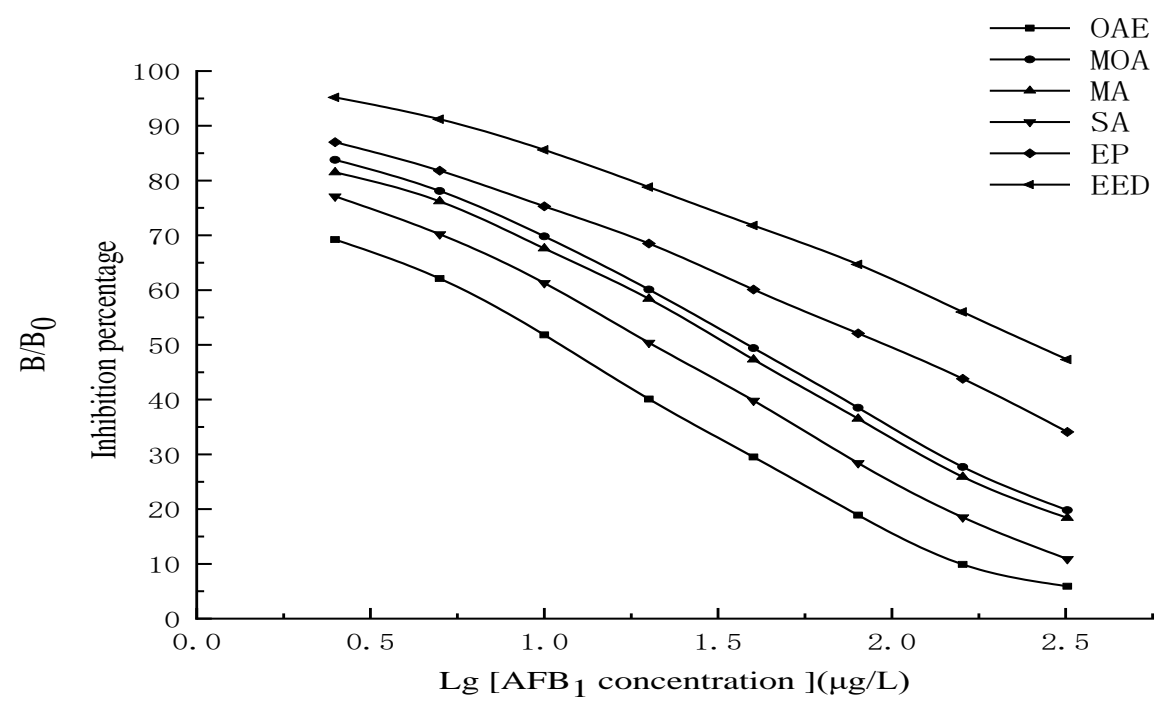

Fig. 5 The sensitivity measurement of $\mathrm{AFB}_{1} \mathrm{pAb}$ to $\mathrm{AFB}_{1}$ by icELISA

Table 3

The regression equation, $R^{2}$ and $I_{50}$ of $4 \mathrm{AFB}_{1} \mathrm{pAb}$ to $\mathrm{AFB}_{1}$ by icELISA

\begin{tabular}{|c|c|c|c|}
\hline group & Regression equation & $\mathrm{R}^{2}$ value & $I_{50}\left(\mu \mathrm{g} \cdot \mathrm{kg}^{-1}\right)$ \\
\hline OAE & $\mathrm{y}=-32.171 \mathrm{x}+82.621$ & 0.9916 & 3.32 \\
\hline MOA & $\mathrm{y}=-31.822 \mathrm{x}+99.59$ & 0.9943 & 31.49 \\
\hline MA & $\mathrm{y}=-31.546 \mathrm{x}+97.263$ & 0.9938 & 18.36 \\
\hline SA & $\mathrm{y}=-32.875 \mathrm{x}+92.292$ & 0.9966 & 91.21 \\
\hline
\end{tabular}

Specificity and broad-spectrum analysis

The results are shown in Table 4. It can be seen that the antibodies prepared by the six methods can recognize $\mathrm{AFB}_{1}$ $100 \%$, and the OAE method has the best specificity and broadspectrum, with an $\mathrm{IC}_{50}$ of $10.32 \mu \mathrm{g} \cdot \mathrm{kg}^{-1}$ and a CR with $\mathrm{AFB}_{2}$ of $86.46 \%$; The $\mathrm{CR}$ with $\mathrm{AFG}_{1}$ and $\mathrm{AFG}_{2}$ were $44.13 \%$ and $14.72 \%$, respectively. Antibodies prepared by other methods have good specificity and can recognize $\mathrm{AFB}_{1} 100 \%$, but their sensitivity and broad-spectrum are not as good as those prepared by OAE method. The results show that the best antigen synthesis method for preparing antibodies against BGAFs with high sensitivity, strong specificity and good broad spectrum is the OAE method.

The percent cross-reactivity of AFB1 pAb with AFB1、AFB2、AFG1、AFG2

\begin{tabular}{|c|c|c|c|c|c|c|c|c|c|c|c|c|}
\hline \multirow[b]{2}{*}{$\mathrm{AF}$} & \multicolumn{2}{|c|}{$\mathrm{AFB}_{1} \mathrm{pAb}(\mathrm{OAE})$} & \multicolumn{2}{|c|}{$\mathrm{AFB}_{1} \mathrm{pAb}(\mathrm{MOA})$} & \multicolumn{2}{|c|}{$\mathrm{AFB}_{1} \mathrm{pAb}(\mathrm{MA})$} & \multicolumn{2}{|c|}{$\mathrm{AFB}_{1} \mathrm{pAb}(\mathrm{SA})$} & \multicolumn{2}{|c|}{$\mathrm{AFB}_{1} \mathrm{pAb}(\mathrm{EP})$} & \multicolumn{2}{|c|}{$\mathrm{AFB}_{1} \mathrm{pAb}(\mathrm{EED})$} \\
\hline & $\begin{array}{c}I C_{50} \\
\left(\mu \mathrm{g} \cdot \mathrm{kg}^{-1}\right)\end{array}$ & $\begin{array}{l}\%) \\
\text { CR }\end{array}$ & $\begin{array}{c}I C_{50} \\
\left(\mu \mathrm{g} \cdot \mathrm{kg}^{-1}\right)\end{array}$ & $\begin{array}{l}\%) \\
\text { CR }\end{array}$ & $\begin{array}{c}I C_{50} \\
\left(\mu \mathrm{g} \cdot \mathrm{kg}^{-1}\right)\end{array}$ & $\begin{array}{l}(\%) \\
\text { CR }\end{array}$ & $\begin{array}{c}I C_{50} \\
\left(\mu \mathrm{g} \cdot \mathrm{kg}^{-1}\right)\end{array}$ & $\begin{array}{l}\%) \\
\text { CR }\end{array}$ & $\begin{array}{c}I C_{50} \\
\left(\mu \mathrm{g} \cdot \mathrm{kg}^{-1}\right)\end{array}$ & $\begin{array}{l}\%) \\
\text { CR }\end{array}$ & $\begin{array}{c}I C_{50} \\
\left(\mu \mathrm{g} \cdot \mathrm{kg}^{-1}\right)\end{array}$ & $\begin{array}{l}\%) \\
\text { CR }\end{array}$ \\
\hline $\mathrm{AFB}_{1}$ & 10.32 & 100 & 36.18 & 100 & 31.49 & 100 & 19.36 & 100 & 91.21 & 100 & 307.81 & 100 \\
\hline $\mathrm{AFB}_{2}$ & 13.72 & 75.21 & 46.03 & 78.61 & 46.85 & 67.22 & 23.83 & 81.26 & 144.14 & 63.28 & 590.13 & 52.16 \\
\hline $\mathrm{AFG}_{1}$ & 23.39 & 44.13 & $>10^{3}$ & $<0.5$ & $>10^{3}$ & $<0.5$ & 35.67 & 54.27 & $>10^{3}$ & $<0.5$ & $>10^{3}$ & $<0.5$ \\
\hline $\mathrm{AFG}_{2}$ & 70.11 & 14.72 & $>10^{3}$ & $<0.5$ & $>10^{3}$ & $<0.5$ & 79.41 & 24.38 & $>10^{3}$ & $<0.5$ & $>10^{3}$ & $<0.5$ \\
\hline AFM & 63.08 & 16.36 & 741.39 & 4.88 & 615.04 & 5.12 & 541.74 & 3.68 & $>10^{3}$ & $<0.5$ & $>10^{3}$ & $<0.5$ \\
\hline AFM & 716.67 & 1.44 & $>10^{3}$ & $<0.5$ & $>10^{3}$ & $<0.5$ & $>10^{3}$ & $<0.5$ & $>10^{3}$ & $<0.5$ & $>10^{3}$ & $<0.5$ \\
\hline
\end{tabular}

Discussion and Conclusion

About the design of BGAFs antigen synthesis method

The molecular weights of $\mathrm{AFB}_{1}$ and $\mathrm{AFB}_{2}$ in $\mathrm{BGAFs}$ are 312.27 and 314.29 , respectively. They belong to small molecule haptens and have no immunogenicity. According to the theory of hapten-carrier effect, only by combining with large-molecule protein carriers to form artificial antigens can they be specific for haptens. Therefore, the design of antigen synthesis methods is very important (Zeng, $\mathrm{H}$. et. al., 2014). Since the selection of different active sites and the introduction of different linking arm lengths will have a greater impact on the properties and structure of small molecules, which in turn will affect the quality of antibodies produced (Shi HY et. al., 2006). According to the molecular structure characteristics of BGAFs, this study selected the 1-position carbonyl group, 2-position active hydrogen, 3position hydroxyl group and aldehyde group, and the difuran ring between 3-position and 4-position as the active groups. Through different chemical reaction methods, respectively introduce available carboxyl, hydroxyl, aminomethyl and other active groups to realize the coupling with carrier protein to synthesize 
artificial antigens.

About the synthetic route of BGAFs artificial antigen

At present, the research on BGAFs artificial antigen synthesis method is still at the empirical level, and trial and error methods are mostly used. Although a variety of artificial antigen identification methods have been established, the immunogenicity of the artificial antigens prepared is ultimately through the effect of animal immunity. It was confirmed (Guo N. F. et. al., 2014). Based on a large number of relevant research literature, this article uses $A F B_{1}$ as the starting material for the reaction, and uses 6 methods such as OAE method, MOA method, MA method, SA method, EP method and EED method to synthesize artificial antigens, and through UV, SDS-PAGE for antigen identification and animal immunization for antibody characteristics analysis, the most ideal antigen synthesis method for the preparation of BGAFs antibody was selected by OAE method. Its advantages are that the reaction system is easy to construct, the reaction conditions are mild, the operation steps are simple, and the product yield is high. However, in terms of the advanced nature of the technical route adopted in this research, the research and application of molecular simulation technology, computer-aided technology, etc. Needs to be improved (Morita, I. 2017).

Analysis on the immune effect of BGAFs artificial antigen.

The purpose of this research is to screen out BGAFs artificial antigen synthesis methods, and lay the material and technical foundation for the preparation of high-quality BGAFs antibodies with high sensitivity, strong specificity and broad recognition spectrum. This requires that in the design of BGAFs antigen synthesis, on the one hand, it is necessary to consider the specificity and sensitivity of the antibody to $A F B_{1}$ to meet the detection technology requirements under the $\mathrm{AFB}_{1}$ limit standard; On the other hand, it is necessary to consider the sensitivity and broad-spectrum of the antibody to $\mathrm{AFB}_{2}$ to meet the technical requirements for detection under the BGAFs limit standard (Xie Hui et al. 2017) used MA method to synthesize AFB1-BSA, and screened hybridoma cell $3 \mathrm{~B} 9$ to obtain $A F B_{1}$ mab. The antibody specifically recognizes $A F B_{1}$ with a sensitivity of 1.04 $\mu \mathrm{g} \cdot \mathrm{kg}^{-1}, \mathrm{CR}$ of $\mathrm{AFB}_{2}, \mathrm{AFG}_{1}, \mathrm{AFG}_{2}$, and $\mathrm{AFM}_{1}$ are $2.2 \%, 33.9 \%$, $1.8 \%$, and $5.12 \%$, respectively, which have no $C R$ with $\mathrm{AMF}_{2}$ and poor broad-spectrum. Xiao Zhi et al. used SA method to synthesize $A F B_{1}-B S A$, and screened hybridoma cell $3 A 12$ to obtain $A_{F} B_{1}$ mab. The antibody specifically recognizes $A F B_{1}$ with a sensitivity of $6.1 \mu \mathrm{g}^{\cdot \mathrm{kg}^{-1}}$, and is compatible with $\mathrm{CR}$ of $\mathrm{AFB}_{2}, \mathrm{AFG}_{1}, \mathrm{AFG}_{2}$, and $\mathrm{AMF}_{1}$. They are $7.8 \%, 20.2 \%, 0.6 \%$, and $3.68 \%$, respectively. It has no $\mathrm{CR}$ with $\mathrm{AFM}_{2}$, and it also has the problem of poor broad-spectrum.

\section{Conclusion}

The results of 6 different antigen synthesis methods and the characteristics of the antibodies produced showed that the $\mathrm{OAE}$ method was the best, the produced $\mathrm{AFB}_{1}$ pAb antibody titer was high, and the indirect ELISA titer reached 1: $\left(1.28 \times 10^{4}\right)$; the sensitivity to $\mathrm{AFB}_{1}$ was good, $\mathrm{IC}_{50}$ is 10.32

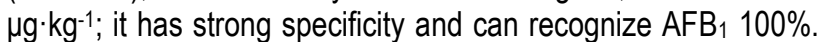
The $\mathrm{CR}$ with $\mathrm{AFB}_{2}, \mathrm{AFG}_{1}, \mathrm{AFG}_{2}, \mathrm{AMF}_{1}$, and $\mathrm{AFM}_{2}$ are $75.21 \%$, $44.13 \%, 14.72 \%, 16.36 \%$ and $1.44 \%$, respectively. The other five methods designed by this research have certain defects in varying degrees. Therefore, the author recommends that they should not be used except for research work.

In this study, based on the molecular structure characteristics of $A F B_{1}$ and the existing active sites, six BGAFs antigen synthesis methods were designed, through UV, SDS-PAGE identification and analysis of the characteristics of $A_{F B} \mathrm{pAb}_{1}$ produced by immunized animals, a high-titer, sensitive, specific, and broad-spectrum $\mathrm{AFB}_{1} \mathrm{pAb}$ was obtained. It shows that antigen synthesis design is the prerequisite for the preparation of high-quality antibodies, and the OAE method is an effective way to realize the preparation of high-quality antibodies for BGAFs, laying a material and technical foundation for the establishment of BGAFs immunoassay methods.

Author's contributions

All authors participated in this article design. Yanan WANG participated and performed writing and data collection. All authors read and approved the final manuscript. All authors contributed to the draft of the manuscript. All authors gave final approval for publication.

Conflict of interest Author does not report any financial or personal connections with other persons or organizations, which might negatively affect the contents of this publication and/or claim authorship rights to this publication.

\section{References:}

1. Sun, D.D.; Gu, X.; Li, J.G.; Yao, T.; Dong, Y.C. (2015). Quality evaluation of five commercial enzyme linked immunosorbent assay kits for detecting aflatoxin b1 in feedstuffs. Asian-Australasian journal of animal sciences 28, 691-696, doi:10.5713/ajas.14.0868.

2. Luo, X.; Li, K.; Xing, J.; Qi, L.; Yang, M.; Wang, R.; Wang, L.; Li, Y.; Chen, Z. (2018). In vivo toxicity assessment of aflatoxin B(1)-contaminated corn after ozone degradation. Food Addit Contam Part A Chem Anal Control Expo Risk Assess 35, 341350, doi:10.1080/19440049.2017.1395518.

3. CHINA. National Food Safety Standard Limit of mycotoxins in food. (2017). Vol. GB 2761 -2017.

4. Gefen, T.; Vaya, J.; Khatib, S.; Rapoport, I.; Lupo, M.; Barnea, E.; Admon, A.; Heller, E.D.; Aizenshtein, E.; Pitcovski, J. (2015). The effect of haptens on protein-carrier immunogenicity. Immunology 144, 116-126, doi:10.1111/imm.12356.

5. Mongkon, W.; Sugita-Konishi, Y.; Chaisri, W.; Suriyasathaporn, W. (2017). Aflatoxin B1 Contamination of Dairy Feeds after Storage in Farm Practice in Tropical Environmen. Biocontrol Sci 22, 41-45, doi:10.4265/bio.22.41.

6. Xiao LW, Xu X, Zhao W, et al. (2017). Study on the development and performance of a paper strip for rapid quantitative detection of aflatoxin B1 based on time-resolved fluorescent nano-spheres. Grain Processing. 42, 41-43.

7. Kolosova, A.Y.; Shim, W.B.; Yang, Z.Y.; Eremin, S.A.; Chung, D.H. (2006). Direct competitive ELISA based on a monoclonal antibody for detection of aflatoxin B1. Stabilization of ELISA kit components and application to grain samples. Anal Bioanal Chem 384, 286-294, doi:10.1007/s00216-005-0103-9.

8. Yu, Y.Y.; Chen, Y.Y.; Gao, X.; Liu, Y.Y.; Zhang, H.Y.; Wang, T.Y. (2018). Nanoparticle based bio-bar code technology for trace analysis of aflatoxin B1 in Chinese herbs. Journal of food and drug analysis. 26, 815-822, doi:10.1016/j.jfda.2017.11.003. 
9. Wang YN, Wang XF, Niu LL, et al. (2016). Research progress in hapten molecule design and immunogen synthesis and antibody characteristics of aflatoxin B1. Science and Technology of Food Industry. 23, 367-376.

10. Zhou, Y.; Wu, J.; Yu, W.; Xu, Y.; Wang, P.; Xie, B.; Chen, F. (2007). Preparation for aflatoxin B(1)-cationized bovine serum albumin based on Mannich-type reaction. J Immunol Methods. 328, 79-88, doi:10.1016/j.jjm.2007.08.009.

11. Rushing, B.R.; Selim, M.I. (2017). Structure and Oxidation of Pyrrole Adducts Formed between Aflatoxin B(2a) and Biological Amines. Chem Res Toxicol, 30, 1275-1285, doi:10.1021/acs.chemrestox.7b00002.

12. Kononenko, G.P.; Burkin, A.A.; Soboleva, N.A. (2002). [Comparative characteristics of immunoreagents based on aflatoxin B1 hemiacetals and sterigmatocystine]. Prikl Biokhim Mikrobiol 38, 571-577.

13. Wang YN, Wang XF, Niu LL, et al. (2017). Advance in immunoassay of total aflatoxins in food. Science and Technology of Food Industry. 13, 344-351.

14. Wang YN, Wang XF, Wang ZL. (2018). Study and application of detection methods of total aflatoxins in food. Food and Fermentation Industries. 44, 1 , 285-290.

15. Cervino, C.; Knopp, D.; Weller, M.G.; Niessner, R. (2007). Novel aflatoxin derivatives and protein conjugates. Molecules 12, 641-653, doi:10.3390/12030641.

16. Wang YN, Wang SY, Zhang HT, et al. (2014). Establishment of Hybridoma Cell Lines Secreting Anti-Cadmium lon Monoclonal Antibody and Identificat of Their Immunological Properties. Acta Agriculturae Boreali-occidentalis Sinica., 11, 24-29.

17. Ju RH, Wen K, Duan LL, et al. (2015). Preparation and Characterization of Polyclonal Antibodies Against Acrylamide. Journal of Nuclear Agricultural Sciences. 29, 10, 1979-1984.

18. Zhao HH, Zhang ZR, Li XJ, et al. (2016). Prokaryotic Expression of Tartary Buckwheat Flavonol SynthaseFtFLS2 and Preparation of Its Polyclonal Antibody. Journal of Nuclear Agricultural Sciences. 30, 2, 240-245.

19. Chen T, Wang CQ, Li XF, et al. (2014). Determination of aflatoxin B1 in peanut under different storage conditions by indirect ELISA. China Oils and Fats. 9, 88-91.

20. Zhang C, Pan JR, Shuai RQ, et al. (2016). Research on Enzyme Linked Immunosorbent Assay for Multi-residues of Nitroimidazoles in Foods of Animal Origin. Journal of Nuclear Agricultural Sciences. 30, 2, 323-331.

21. Liu, H.X.; Yang, Y.X.; Ma, M.G.; Wang, X.M.; Du, X.Z. (2015). Self-assembled Gold Nanoparticles Coating for SolidPhase Microextraction of Ultraviolet Filters in Environmental Water. Chinese Journal of Analytical Chemistry 43, 207-211.

22. Zeng, H.; Chen, J.; Zhang, C.; Huang, X.A.; Sun, Y.; Xu, Z.; Lei, H. (2016). Broad-Specificity Chemiluminescence Enzyme Immunoassay for (Fluoro)quinolones: Hapten Design and Molecular Modeling Study of Antibody Recognition. Anal Chem 88, 3909-3916, doi:10.1021/acs.analchem.6b00082..

23. Shi HY, Wang MH. (2008). Effect of Hapten Space Arm Length on Immune Recognition. Chinese Journal of Pesticide Science. 2, 172-177.

24. Guo NF, Yu JC, Ma FM, et al. (2014). Study of Comparison the Commonly Used Artificial Antigen Identification Methods. Journal of Food Science and Biotechnology. 33 5,517-521.

25. Morita, I.; Oyama, H.; Yasuo, M.; Matsuda, K.; Katagi, K.; Ito, A.; Tatsuda, H.; Tanaka, H.; Morimoto, S.; Kobayashi, N. (2017). Antibody Fragments for On-Site Testing of Cannabinoids Generated via in Vitro Affinity Maturation. Biological \& pharmaceutical bulletin, 40, 174-181, doi:10.1248/bpb.b16-00669.

26. Hayashi, N.; Saegusa, J.; Uto, K.; Oyabu, C.; Saito, T.; Sato, I.; Kawano, S.; Kumagai, S. (2016). Evaluation of a Computer-Aided Microscope System and Its Anti-Nuclear Antibody Test Kit for Indirect Immunofluorescence Assay. Rinsho Byori, 64, 142-151.

27. Wang YN. (2020). Preparation of Broad-Specificity Antibodies and Development of Immuno-chromatographic Strip for Detection of Total Aflatoxins in Animal Food. Henan Institute of Science and Technology.

28. Xie H, Zhang X, Wang X, et al. (2015). Preparation of anti-aflatoxin B1 monoclonal antibodies and its use in an indirect competitive ELISA for aflatoxin B1. Microbiology China. 10, 2033-2040.

29. Xiao Z, Li PW, Zhuang Q, et al. (2011). Production and characteristics of specialised monoclonal antibodies against aflatoxin B1. Chinese Journal of Oil Crop Sciences. 33, 001, 66-70.

Янан Ванг, аспірант Сумський НАУ, (Суми, Україна), Коледж наук про тварин та ветеринарну медицину, Інститут науки і технологій Хенань, (Сіньсян, Китай)

Ганна Фотіна, доктор ветеринарних наук, профресор, Сумський НАУ, (Суми, Україна) латоксинів

Синтез та підготовка антигенів для отримання специфічних і евритопних антитів проти B-group аф-

Метою цього дослідження було вироблення антитіл до афрлатоксинів групи B (BGAF) із сильною специфічністю та хорошою евритопічністю. Дослідження проводили в лабораторії безпеки та якості продуктів тваринництва Сумського НАУ, фракультету ветеринарної медицини, Суми, Україна та на базі Науково-технічного інституту Хенань, Сіньсян, Китай. Відповідно до молекулярної структури та активного центру афрлатоксину B1 (AFB1), итучний антиген BGAFs AFB1-BSA готували 6 ма методами, такими як метод активного ефіру оксиму (OAE), метилювання аміаку (MOA), змішаний ангідрид (MA), напівфрабрикат ацеталь (SA) епоксид (EP) та похідне енолового ефіру (EED) та ідентифікували за допомогою УФ та SDS-PAGE.

Поліклональні антитіла проти AFB1 (AFB1 рAb) готували шляхом імунізації новозеландських кролів AFB1-BSA, а титри AFB1 рАb виявляли за допомогою непрямого IФA, чутливість AFB1 рAb аналізували за допомогою непрямого конкурентного IФA (icELISA), специфрічність та еурітопічність AFB1 рАb аналізували за допомогою тесту перехресної 
реактивності (CR). Результати показали, що AFB1-BSA був успішно синтезований, і найкращим був метод активного есріру оксиму (OAE) із 6 методів синтезу штучного антигену BGAF, а його відношення кон'югації AFB1 до BSA становило близько 8,46À1. Імунна ефрективність методу OAE була найкращою, його рAb AFB1 мав високі титри 1: (1,28×104) 3 використанням методу непрямого ІФА, чутливість з 50\% концентрацією інгібування (IC50) 10,32 мкг / л до AFB1 за допомогою ісELISA та високий CR до AFB2 75,21\%, AFG1 44,13\%, AFG2 14,72\%, AFM1 16,36\% та AFM2 1,44\% відповідно. У цьому дослідженні були підготовлені pAbs AFB1 з високим титром, чутливістю, специфрічністю та еуритопічністю, що заклало важливу та технічну основу для створення імунологічного аналізу BGAF.

Ключові слова: афрлатоксини групи В, конструкція синтезу антигену, поліклональні антитіла, аналіз, характеристики.

Дата надходження до редакції: 20.11.2020 р. 